\title{
PENGUATAN SPIRITUALITAS DAN INTELEKTUALITAS DI MASA PANDEMI COVID-19
}

\author{
Harun Alrasyid*, Khofifah, Siti Rahmania Ridwan, Shalyza Nur Akmalia \\ Fakultas Ekonomi dan Bisnis, Universitas Islam Malang \\ *korespondensi email: thoriqalanshori@unisma.ac.id
}

\begin{abstract}
ABSTRAK
Dewasa ini kita sedang diresahkan dengan penyebaran wabah Covid-19. Hal ini mengakibatkan semua aspek kehidupan manusia terganggu baik dari aspek Intelektualiatas maupun Spiritualitas. Mayoritas siswa siswa di kelurahan dinoyo yang sedang menimba ilmu mengalami kesulitan pada saat menerima materi yang diberikan, sehingga membuat peserta didik lama kelamaan merasa jenuh dan tertekan dengan materi-materi serta tugas-tugas yang diberikan. . Selain itu Covid-19 ini juga mengakibatkan kegiatan anak-anak TPQ AlMuhajirin tidak berjalan sesuai dengan yang diharapkan. Dari permasalahan diatas dapat diatasi dengan beberapa metode yakni pendampingan belajar online dan mengajar mengaji yang dipandang cukup efisien untuk peserta didik dalam meningkatkan nilai intelektualitas serta spiritualitas. Kegiatan KSM-TEMATIK Universitas Islam Malang dilaksanakan secara langsung pada tanggal 02 Agustus 2021-14 September 2021 di Kelurahan Dinoyo RW 06 Malang. Mengukuhkan kemampuan pengambdian masyarakat melalui penguatan intelektualitas dan spiritualitas yang dapat berperan dalam menunjang keberhasilan yang merupakan salah satu program kegiatan KSM-TEMATIK Universitas Islam Malang.
\end{abstract}

Kata Kunci: intelektualitas; spiritualitas

\section{PENDAHULUAN}

Pandemic Fatigue yang diakibatkan oleh adanya covid-19 masih saja menghantui orang-orang tanpa memandang status, usia, budaya, kewarganegaraan dan sebagainya (Dianti \& Ekawati, 2021). Pandemi global yang kian hari semakin meningkat turut mempengaruhi hampir semua aspek kehidupan manusia. Penyebaran Virus Covid-19 yang tak kunjung usai, mengakibatkan banyak dari kita terpaksa menerima kenyaaan pahit ini. Kehilangan orang-orang tercinta, kehilangan mata pencaharian, semua serba dirumahkan, serta gangguan kesehatan mental yang disebabkan oleh adanya Covid-19 (Fadlika et al., 2021).

Kasus positif Covid-19 semakin hari semakin meningkat, hal tersebut menyebabkan pemerintah mengambil tindakan PPKM di bebrapa daerah termaksud Jawa Timur (Budiman, 2021). Dengan adanya PPKM ini menyebabkan kegiatan TPQ Al-Muhajirin tidak dapat berjalan dengan semestinya. Sehingga anak-anak di TPQ terpaksa diliburkan. Hal ini mengakibatkan menurunya spiritualitas pada anak-anak. Spiritualitas merupakan keyakinan yang mendasari adanya suatu kekuatan yang mengatur alam semesta. Adanya spiritualitas, mendorong individu untuk memaknai nilai-nilai kehidupan, berkomitmen dan bertanggung jawab (Hudha, 2012). Hubungan yang mendasari spiritualitas memiliki 4 karakteristik diantaranya yaitu hubungan dengan diri sendiri, hubungan dengan alam, 
hubungan dengan orang lain, dan hubungan dengan tuhan. Kebutuhan spiritual merupakan kebutuhan untuk mencari arti dan tujuan hidup, kebutuhan untuk mencintai dan dicintai serta rasa keterikatan, kebutuhan untuk memberikan dan mendapatkan maaf (Frager, 2014). Kekuatan spriritual seseorang yang masih minim dapat memicu terjadinya permasalahan di kesehatan yakni psikososial.

Pandemi Covid-19 selain menimbulkan dampak di atas, juga berdampak bagi keberlangsungan pembelajaran. Dampak tersebut sangat dirasakan oleh semua orang, baik didesa maupun dikota. Belajar dari rumah secara daring adalah hal baru bagi masyarakat Indonesia. Sumarno (2020) menyatakan bahwa kegiatan esensial yang harusnya dilakukan di sekolah berubah dilakukan di rumah siswa masing, dan kebanyakan proses pembelajaran yang dilakukan antara guru dengan murid ini dilaksanakan dengan keadaan seadanya tanpa persiapan lebih matang.

Belajar Daring menimbulkan beberapa masalah diantaranya kurangnya pengetahuan tentang teknologi informasi oleh siswa mapun orang tua siswa, pembelajaran menjadi membosankan dan penilaian pembelajaran yang seharusnya bisa dilakukan secara langsung jadi tidak bisa dilakukan (Prawanti \& Sumarni, 2020). Hal tersebut menjadikan peserta didik malas untuk belajar secara daring karena kurangnya motivasi dan perhatian dari orang tua. Sehingga akan berdampak pada menurunnya intelektualitas para peserta didik. Secara bahasa intelektualitas berkonotosi dengan kecerdasan. Intelektualitas mengandung arti cerdas, cendekia, pintar dan mempunyai keilmuan (Pakpahan, 2021). Maka penguatan intelektualitas merupakan hal yang sangat penting bagi peserta didik.

Berangkat dari permasalahan di atas, KSM 48 Universitas Islam Malang mengambil sebuah langkah yang cukup efektif yakni metode penguatan spiritualitas dan intelektual melalui pendampingan belajar daring serta kegiatan mengajar mengaji di TPQ Al-Muhajirin pada RW 06 Kelurahan Dinoyo, Kecamatan Lowokwaru.

\section{METODE}

Pengabdian ini dilaksanakan oleh mahasiswa Kandidat Sarjana Mengabdi (KSM) Tematik Universitas Islam Malang, Kelompok KSM 48 di RW 06 Kelurahan Dinoyo, Kecamatan Lowokwaru, Kota Malang Tahun 2021 Akademik 2021/2022. Berkolaborasi dengan Dosen Pembimbing Lapangan, dilaksanakan secara langsung pada tanggal 02 Agustus - 14 September 2021.

Metode dalam program ini menggunakan pendekatan kualitatif dengan metode deskriptif. Penelitian Kualitatif sebagai human instrument, berfungsi menetapkan focus penelitian, memilih informasi sebagai sumber data, melakukan pengumpulan data, menafsirkan data dan membuat kesimpulan atas semuanya (Sugiyono, 2019).

Program pada kegiatan KSM Tematik ini dibagi menjadi 3 tahapan yaitu diantaranya: Tahap pertama adalah melakukan sosialisasi kepada Ta'mir Masjid selaku pengurus TPQ AlMuhajirin dan kepadaa bapak lurah setempat untuk mendapatkan persetujuan melakukan program yang telah ditentukan. Tahap kedua adalah tahap pendampingan peserta didik dalam rangka penguatan spiritualitas dan intelektualitas pada RW 06 Kelurahan Dinoyo. Tahap yang terakhir adalah melakukan evaluasi terkait keberhasilan dari program tersebut.

\section{HASIL DAN PEMBAHASAN}

Pelaksanaan program penguatan spriritualitas dan intelektualitas di kelurahan Dinoyo dilakukan dengan 4 tahapan, dimulai sejak tanggal 2 Agustus 2021. Program ini dilakukan di dua tempat yaitu di TPQ Al- Muhajirin dan di rumah salah satu wali murid.

Pertama, Adanya sosialisasi yang dilakukan oleh mahasiswa kepada Bapak lurah dan kepada Ta'mir Masjid. Sosialisasi kepada Bapak Lurah dilaksanakan pada tanggal 02 Agustus 
2021, sosialisasi ini dilakukan untuk menyampaikan program kerja penguatan intelektualitas pada masa Pandemi Covid-19. Dimana banyak peserta didik yang mengalami kendala saat belajar daring, sehingga dari segi intelektualitas peserta didik sedikit menurun pada saat ini. Sehingga mahasiswa memberikan solusi dengan program penguatan intelektualitas pada masa Pandemi Covid-19. Program ini akan dilaksanakan di Rumah salah satu peserta didik, di RW 06 Kelurahan Dinoyo dengan memberikan pendampingan belajar, menjelaskan materi yang belum dipahami oleh peserta didik, serta beberapa mini game agar peserta didik tidak merasa jenuh saat pembelajaran berlangsung. Hal tersebut dilakukan bertujuan agar intelektualitas peserta didik tetap kuat walaupun saat belajar daring.

Sosialisasi juga dilakukan kepada Ta'mir Masjid Al-Muhajirin pada tanggal 08 Agustus 2021, sosialisasi tersebut juga untuk menyampaikan program kerja penguatan spiritualitas anak pada masa Pandemi Covid-19. Peraturan pemerintah tentang PPKM yang melarang adanya kegiatan yang memicu kerumunan menjadikan TPQ AL-Muhajirin juga terpaksa diliburkan sementara waktu, hal tersebut berdampak kepada menurunnya spiritualitas pada anak-anak. Sehingga mahasiswa memberikan solusi dengan program penguatan spiritualitas pada masa Pandemi Covid-19. Program ini akan dilaksanakan di TPQ ALMuhajirin dengan memberikan pembelajaran yang berkaitan dengan spiritualitas, tentunya dengan tetap melakukan protokol kesehatan agar tidak melanggar aturan PPKM.

Kedua, Kegiatan penguatan intelektualitas berupa pendampingan belajar pada siswa SD di Kelurahan Dinoyo. Kegiatan tersebut dilaksanakan 1 minggu 5 kali yaitu Senin-Jumat setiap pukul 09.30-12.30 agar peserta didik dapat belajar secara maksimal. Kegiatan pendampingan belajar daring dilaksanakan di salah satu rumah wali murid, tepatnya di kediaman Ibu Tari. Kegiatan pendampingan belajar menggunakan metode pembelajaran ceramah plus yaitu mahasiswa terlebih dahulu menjelaskan materi pelajaran, selanjutnya peserta didik melakukan diskusi terkait topik yang sedang dipelajari, dilanjutkan dengan sesi tanya jawab, peserta didik bisa menanyakan tentang materi yang belum dipahami, dan selanjutnya mahasiswa memberikan soal latihan agar peserta didik dapat lebih memahami materi yang dibahas. Selain itu agar peserta didik tidak merasa jenuh saat proses pembelajaran mahasiswa juga mengadakan mini game disela-sela waktu belajar, dengan begitu para peserta didik akan lebih semangat dan proses pembelajaran menjadi lebih aktif dan menyenangkan. Program ini bertujuan agar intelektualitas para peserta didik tetap kuat walaupun tidak belajar langsung di sekolah.

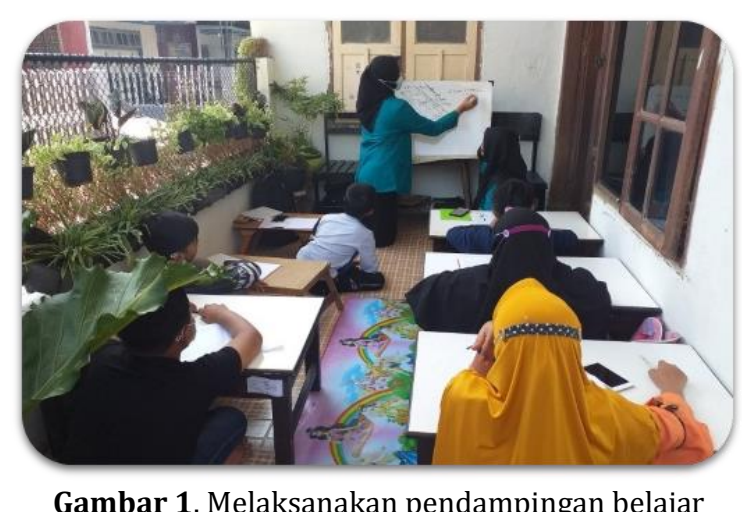

Gambar 1. Melaksanakan pendampingan belajar 


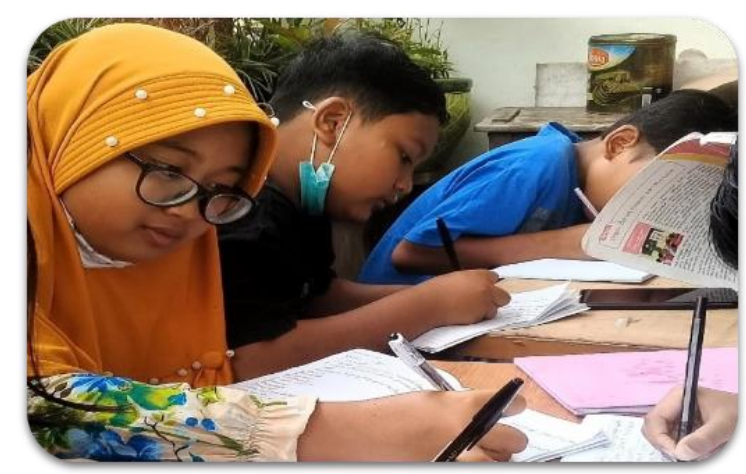

Gambar 2. Peserta didik mengerjakan latihan soal

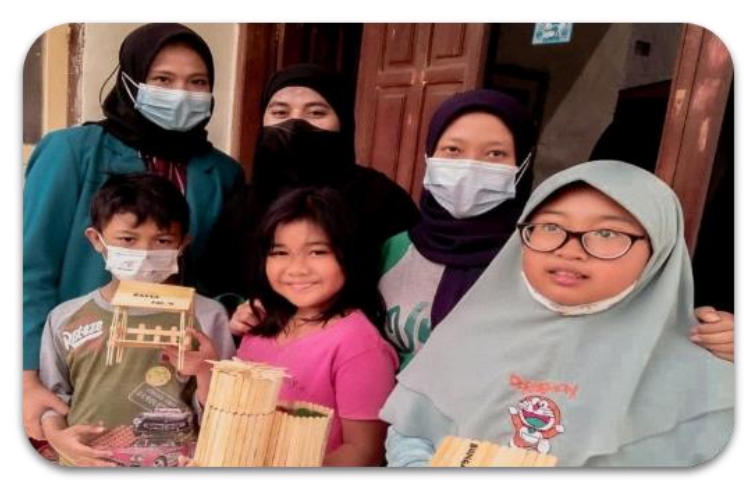

Gambar 3. Peserta didik membuat kerajinan guna mengasah kreatifitas

Ketiga, Kegiatan penguatan spiritualitas berupa pembelajaran yang berkaitan dengan spiritual seperti pembelajaran mengaji, dan materi dasar-dasar tentang agama. Kegiatan ini dilaksanakan 1 minggu 4 kali yaitu Senin-Kamis setiap pukul 15.30-17.00. Kegiatan tersebut dilaksanakan di TPQ Al-Muhajirin yang mayoritas peserta didiknya masih duduk di Sekolah Dasar. Kegiatan pembelajaran tersebut menggunakan metode demonstrasi, dimana peserta didik secara individu mempraktikkan secara langsung mengaji kepada mahasiswa dan guru pengajar. Sehingga para pengajar bisa langsung mengkoreksi jika terdapat kesalahan.

Selain menggunakan metode pembelajaran demonstrasi, di TPQ Al-Muhajirin juga menggunakan metode pembelajaran ceramah, dimana para pengajar menjelaskan materi tentang dasar-dasar agama, seperti materi tentang sholat, akhlak, aqidah, dan lain-lain.

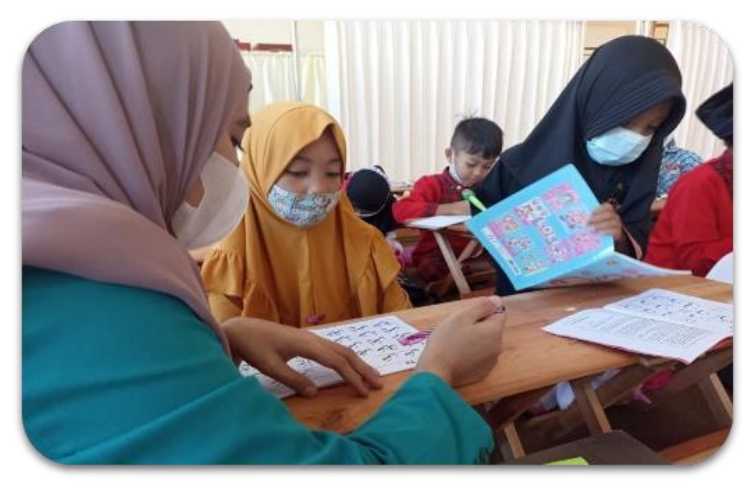

Gambar 4. Peserta didik mengaji kepada mahasiswa 


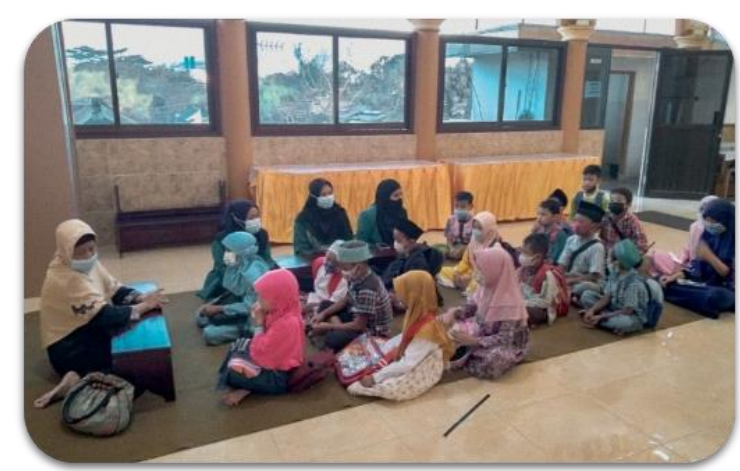

Gambar 5. Peserta didik menyimak penjelasanmateri yang disampaikan ustadzah

\section{KESIMPULAN}

Kegiatan KSM-Tematik (Kandidat Sarjana Mengabdi) Universitas Islam Malang yang dilaksanakan secara langsung pada tanggal 02 Agustus 2021-14 September 2021 di Kelurahan Dinoyo RW 06 Malang. Melalui kegiatan program unggulan yang dilakukan oleh mahasiswa KSM-TEMATIK Universitas Islam Malang yakni penguatan intelektualitas dan spiritualitas yang mana disambut dengan baik oleh masyarakat. Namun demikian terdapat beberapa kendala diantaranya para siswa mengalami kesulitan pada saat menerima materi yang diberikan, sehingga membuat mereka lama kelamaan merasa jenuh dan tertekan dengan materi-materi serta tugas-tugas yang diberikan dan juga mengakibatkan kegiatan mengaji anak-anak TPQ Al-Muhajirin tidak berjalan sesuai dengan yang diharapkan. Sehingga pentingnya peran dari KSM-TEMATIK Universitas Islam Malang sangat dibutuhkan karena dapat menguatkan spiritualitas dan intelektualitas pada masa Pandemi Covid-19 dengan memberi bantuan pendidikan berupa pendampingan belajar online dan mengajar mengaji di TPQ Al-Muhajirin.

\section{UCAPAN TERIMA KASIH}

Ucapan terima kasih disampaikan kepada LPPM UNISMA yang memberikan kesempatan dan kemudahan kepada kami untuk melakukan kegiatan KSM-Tematik. Ucapan terima kasih juga disampaikan kepada Kepala Desa Kelurahan Dinoyo beserta masyarakat Rw.06 kelurahan Dinoyo, Kecamatan Lowokwaru, Kabupaten Malang khususnya ketua Ta'mir masjid Al-Mujahirin yang telah memberikan izin dan membantu melancarkan kegiatan program kerja selama masa KSM-Tematik berlangsung.

\section{DAFTAR RUJUKAN}

Budiman, M. A. K. (2021). Pandemi Covid-19: Menjaga dan Menyelamatkan Lingkungan Hidup. KEMNKO PMK. https://www.kemenkopmk.go.id/pandemi-covid-19menjaga-dan-menyelamatkan-lingkungan-hidup

Dianti, T., \& Ekawati, A. (2021). Pandemic Fatigue, Kelelahan Tak Berujung Membuat Orang Tidak Peduli. DW. https://www.dw.com/id/pandemic-fatigue-kelelahan-takberujung-memicu-orang-tidak-peduli/a-58037361

Fadlika, I., Aripriharta, Dwiwahyono, I., Andriansyah, M. R., Gunawan, M. R., Mistakim, E., \& Fakhri, A. S. (2021). Pengembangan alat sterilisasi mikroorganisme dan pelaksanaan disinfeksi berkala sebagai upaya untuk memutus rantai penularan covid-19. Jurnal Inovasi Hasil Pengabdian Masyarakat (JIPEMAS), 4(3). https://doi.org/10.33474/jipemas.v4i3.11007

Frager, R. (2014). Psikologi Sufi untuk Transformasi Hati, Jiwa, dan Ruh. Zaman.

Hudha, A. M. (2012). Menjadi Pribadi Inovatif, Kreatif, dan Mandiri yang Berspiritualitas. Aditya Media Publishing. 
Pakpahan, D. P. (2021). Kecerdasan Spiritual (SQ) dan Kecerdasan Intelektual (IQ) dalam Moralitas Remaja Berpacaran Upaya Mewujudkan Manusia yang Seutuhnya. Ahlimedia Book.

Prawanti, L. T., \& Sumarni, W. (2020). Kendala Pembelajaran Daring Selama Pandemic Covid19. Seminar Nasional Pascasarjana (Prosnampas), 286-291. https://proceeding.unnes.ac.id/index.php/snpasca/article/view/603

Sugiyono. (2019). Metode Penelitian Kuantitatif Kualitatif dan R\&D. Alfabeta.

Sumarno. (2020). Adaptasi Sekolah Dalam Mengimplementasikan Pembelajaran Jarak Jauh Pada Masa Pandemi Covid-19 (Studi Kasus Smp Muhammadiyah Karanggeneng Kabupaten Lamongan). Jurnal Tarbiyah \& Ilmu Keguruan (JTIK) Borneo, I(2), 149162. https://journal.uinsi.ac.id/index.php/JTIKBorneo/article/view/2435 